\title{
Seropositivity to herpes simplex virus type 2 , but not type 1 is associated with cervical cancer: NHANES (1999-2014)
}

Sen $\mathrm{Li}^{1,2^{*}}$ (D) and Xi Wen ${ }^{3}$

\begin{abstract}
Background: Herpes simplex virus types 1 and 2 (HSV1 and HSV2) are infectious agents, and their association with cancer occurrence in human is a controversial topic for decades. We addressed this subject using all available continuous National Health and Nutrition Examination Survey (NHANES) cross-sectional data from 1999 to 2014.

Methods: Eight data cycles (1999-2000, 2001-2002, 2003-2004, 2005-2006, 2007-2008, 2009-2010, 2011-2012, and 2013-2014) were employed, and a sample of 8184 female participants was used in this study according to the availability of cancer history and HSV serostatus.

Results: The seroprevalences of HSV1 and HSV2 were $60.73 \pm 0.89$ and $25.02 \pm 0.64$, respectively, and the numbers increased with age $(P<0.01)$. In confounder-adjusted logistic regression analysis, association between HSV1 seropositivity and uterine cancer was identified (adjusted odds ratio-OR $\mathrm{R}_{\text {adjusted }}=6.03 ; 95 \% \mathrm{Cl}: 1.52,23.87$ ). HSV2 seropositivity was associated with cancer occurrence $\left(\mathrm{OR}_{\mathrm{adj} u s t e d}=1.47 ; 95 \% \mathrm{Cl}: 1.01,2.14\right)$, cervical cancer $\left(\mathrm{OR}_{\text {adjusted }}=1.72 ; 95 \%\right.$ Cl: 1.06, 2. 79) and uterine cancer $\left(\mathrm{OR}_{\text {adjusted }}=3.49 ; 95 \% \mathrm{Cl}\right.$ : 1.03, 11.85). Moreover, HSV2 was persistently associated with cervical cancer after further adjusting high-risk human papillomavirus (HPV) as confounder ( $\mathrm{OR}_{\text {adjusted }}=1.90 ; 95 \% \mathrm{Cl}$ : 1.09, 3.34). Relative risk (RR)-based interaction measurement between HSV2 and HPV on the additive scale suggests higher RR for cervical cancer in participants with seropositivity for HPV only ( $R_{\text {adjusted }}=2.98 ; 95 \% \mathrm{Cl}: 1.23,7.20 ; P=0.02$ ), HSV2 only $\left(\mathrm{RR}_{\mathrm{adj} j \mathrm{sted}}=2.79 ; 95 \% \mathrm{Cl}: 1.31,5.96 ; P=0.01\right)$ or both viruses $\left(\mathrm{RR}_{\mathrm{adj}} \mathrm{fsted}=3.44 ; 95 \% \mathrm{Cl}: 1.50,7.86 ; P<0.01\right)$ when setting participants with seronegativity for both HPV and HSV2 as reference.
\end{abstract}

Conclusions: The finding of current study provides epidemiological evidence that serostatus of HSV2 can serve as an independent predictor for cervical cancer.

Keywords: Cervical cancer, HSV, HPV, NHANES

\section{Background}

Cervical cancer represents the fourth most common cancer among women globally: It accounts for $7.9 \%$ of total cancer cases in females. 528,000 newly occurred cases and 266,000 deaths were estimated in 2012 [1, 2]. In the United States, the estimated cervical cancerrelated emerging cases and deaths are 12,990 and 4120, respectively, in 2016 [3]. Cervical cancer mainly affects countries with low or medium levels of human

\footnotetext{
* Correspondence: senli@bucm.edu.cn

'School of Life Sciences, Beijing University of Chinese Medicine, Beijing, China

2Department of Physiology, LKS Faculty of Medicine, University of Hong Kong, Hong Kong, China

Full list of author information is available at the end of the article
}

development, and its incidence rates vary significantly from country to country with a range of $3.8 / 100,000$ in Israel to $48.2 / 100,000$ in Colombia for each year [4]. Early changes in cervix (e.g. squamous intraepithelial lesions) can be detected years before malignancy by screening tests like Pap smear, and such primary screening has resulted in declined incidences of cervical cancer in several countries over the past 30 years. Due to its characteristics of being sexually transmitted, cervical cancer is deemed as sexually transmitted cancer [5]. Indeed, recent changes in sexual behavior have led to increase in risk of HPV infection, thereby elevating cervical cancer incidences in several eastern European countries and former Soviet states [1]. 
Individuals with HSV1 or HSV2 infection become lifelong carriers. In 2005-2010, the seroprevalences of HSV1 and 2 were $53.9 \%$ and $15.7 \%$, respectively, among $14-$ to 49-year-olds in the United States [6]. As characterized by oral-labial lesions, HSV1 infection is generally transmitted nonsexually while HSV2, as one of the most common sexually transmitted diseases (STDs), is predominantly transmitted from sexual partner with unrecognized or asymptomatic disease. Because of its role in facilitating HIV acquisition and transmission, prevalence and epidemiology of HSV2 have been more frequently described than that of HSV1 [6]. However, it is of note that HSV1 can also be a significant cause of genital herpes in individuals with oral-genital contact [7].

Despite many decades of investigation, the question whether cervical cancer can be induced by herpes viruses is still in debate. HSV2 was hypothesized to be the cervical cancer-inducing sexually-transmitted factor even earlier than HPV $[4,5]$ : higher rates of HSV2 antibodies have been found in patients with cervical cancer compared to control as early as the second half of twentieth Century [8-10]. However, this opinion has been weakened by some of the epidemiologic studies, along with the lack of detection of HSV2 DNA in cervical tissues [11]. Thus, the proposed aetiological link between HSV2 and cervical carcinoma remains unproved [12]. On the other hand, HSV1 is capable of interfering with DNA repairing and inducing genetic modifications in acute lymphoblastic leukemia [13]. Moreover, HSV1 is found to play a role in thyroid carcinogenesis [14]. To address this subject of an active controversy, current study was performed using the NHANES data with following specific aims: 1) to examine whether HSV1 and 2 were independent risk factors for occurrence of any or femalespecific types of cancer, and 2) to evaluate the combined effect of HSV2 and high-risk HPV seropositivity for the development of cervical cancer, and possible interaction between HSV2 and HPV in cervical carcinogenesis.

\section{Methods}

\section{Study population}

Continuous NHANES is a population-based nationwide complex survey to collect and evaluate health and nutrition condition of the non-institutional civilian U.S. population [15]. The survey data is released by U.S. National Centers for Health Statistics (NCHS) biannually for public use since 1999, and NHANES has been approved by National Health Statistics Institutional Review Board. In this study, data from all eight available survey cycles (1999-2014) were employed, which contains a total of 39,755 U.S. female participants. Status of HSV1 and HSV2 infection were measured in the 14-49 years old subgroup in each data-cycle. After excluding subjects with missing $(n=27,566)$ or indeterminate $(n=73)$
HSV1 or HSV2 measurement, a total 12,116 females had HSV serostatus. In this population, subjects who lacked information on whether having cancer $(n=1545)$ or failed to provide specific cancer type $(n=7)$ were also excluded, leaving 10,564 female participants, aged 20 years or older, with cancer status. Next, participants with insufficient information on other variables ( $n=1949)$ or received HPV vaccination $(n=431)$ were also removed, leading to a final study population of 8184 females (Additional file 1: Figure S1). For HPV-related analysis, only four data-cycles (2003-2010) were employed due to the availability of serum HPV test, and 4298 female participants were included in the analyses.

\section{HSV and HPV serostatus}

Blood samples were collected from eligible subjects at mobile examination center, and shipped to Emory University or CDC for HSV or HPV analysis, respectively. Serostatus of HSV1 and HSV2 were accessed by solid-phase enzymatic immunodot assay using virus type-specific purified glycoprotein as antigen, and the outcomes were categorized as positive, negative and indeterminate. Competitive Multiplexed Luminex Assay was employed to determine HPV serostatus by simultaneously measuring antibodies against HPV-16 and -18. Readouts of this assay were quantitative, and were presented as arbitrary units (milliMerck units $/ \mathrm{ml}$ ). Threshold for positive results were defined to generate qualitative results (positive-at or above threshold; negative-below threshold) for HPV-16 and -18. Multiplexing the assay has little to no effect on the simplex standard curves for HPV-16 and -18 (the only two types of HPV, as high-risk HPV types, that have been employed in current work), revealing limited crossreactivity [16]. The detailed methodology is available in the NHANES laboratory procedure manual [17]. For analytic purpose, four additional variables were created: seropositivity for HSV1 or HSV2, both HSV1 and HSV2, HPV (types 16 or 18 , as high-risk HPV types), and both HPV and HSV2.

\section{Cancer status}

Cancer status was judged based on answers to the question "Have you ever been told by a doctor or other health professional that you had cancer or a malignancy of any kind?" and its subsequent question "What kind of cancer was it?" in medical condition questionnaire. Occurrence of any type of cancer (any cancer) and four specific female-related cancers were present in this study.

\section{Other variables}

The associations between status of cancer and HSV/ HPV seropositivity were adjusted for a series of potential confounding factors: age (20-29, 30-39 or 40-49), race/ ethnicity (Non-Hispanic white, Non-Hispanic black or 
others), education (<high school, high school or $>$ high school), poverty income ratio (PIR; $<1,1 \leq \mathrm{PIR} \leq$ median or $>$ median, where medians were computed based on PIR $\geq 1$ for each of the eight data cycles), body mass index (BMI; $<25 \mathrm{kgm}^{-2}$ or $\geq 25 \mathrm{kgm}^{-2}$, where BMI $\geq 25 \mathrm{kgm}^{-2}$ indicates overweight based on NIH health guidelines).

Current smokers were defined as participants who had smoked $\geq 100$ cigarettes during their lifetimes and reported smoking every day or on some days at the time of interview while former smokers were subjects who smoked $\geq 100$ cigarettes during their lifetimes but were not currently smoking at the time of interview. Participants who smoked less than 100 cigarettes were defined as nonsmokers. Current drinkers were participants who had $\geq 12$ drinks of any type of alcoholic beverage in any one year, and had ever drunk over the past 12 months. Former drinkers were subjects who had $\geq 12$ drinks but none in the past year. Subjects who had less than 12 drinks in any one year were defined as non-drinkers. HIV status (positive or negative) was determined by HIV antibody test result. HPV vaccine was first introduced in 2006, and HPV vaccination status was based on the question "Have you ever received one or more doses of the HPV vaccine?" in NHANES 2007-2014 Immunization section. Moreover, weighted percent of HPV vaccination according to survey cycles and age was given in Additional file 2: Figure S2.

\section{Statistical analysis}

The weighted seroprevalences of HSV1 and HSV2 were calculated based on overall data, and data stratified by age, race/ethnicity as well as cancer status. Adjusted odds ratio $\left(\mathrm{OR}_{\text {adjusted }}\right)$ and $95 \%$ confidence intervals (CIs) for the associations between HSV/HPV and cancer status (any or specific female-related cancer type) were obtained by logistic regression, and the confoundersadjusted models were run with HSV1, HSV2 or HPV16/ 18 on female-only dataset. Statistical analysis were performed using SAS 9.4 software (SAS Institute Inc., Cary, $\mathrm{NC}$ ), and the re-calculated sample weights for combined 1999-2014 data, stratification and clustering design variables were integrated into SAS survey procedures.

\section{Results}

Summary statistics of the study population consisting of female participants aged 20-49 years from NHANES 1999-2014 $(n=8184)$ were described in Table 1 . The average age of the subjects was $35.44 \pm 0.14$, and they were equally distributed into three age categories according to the weighted percentage. Only participants aged below 50 years were included in our study due to availability of HSV1 and HSV2 serostatus, leading to relatively young average age. Weighted prevalence of occurrence of any type of cancer or cervical cancer according to age was given in Additional file 3: Figure S3.
About $67 \%$ of the included participants were nonHispanic whites while $12 \%$ were non-Hispanic black. Other ethnicities represented $21 \%$ of study population. Approximately $14 \%$ of the study population had been educated less than high school. About $17 \%$ of subjects came from low income families (PIR $<1$ ), and $60 \%$ of the participants were overweight or obese reflected by BMI $\geq 25 \mathrm{kgm}^{-2}$. Current and former smoker represented $24 \%$ and $16 \%$ of the study population, respectively, while $66 \%$ and $6 \%$ were current and former alcohol user, respectively. The incidence of occurrence of any type of cancer (includes, but is not limited to, the following four female-related cancers), breast cancer, cervical cancer, ovarian cancer and uterine cancer were $4.90 \pm 0.32,0.48 \pm 0.10,1.79 \pm 0.19,0.30 \pm 0.08$ and $0.38 \pm 0.09$, respectively.

The seroprevalence of HSV type 1 and 2 were $60.73 \pm 0.89$ and $25.02 \pm 0.64$, respectively, for the total population. For the eight data cycles from 1999 to 2014, HSV incidences did not vary a lot with a range of $56.63 \pm 2.51$ to $64.87 \pm 1.35$ for HSV1, and $20.93 \pm 2.31$ to $28.29 \pm 2.15$ for HSV2 (Additional file 4: Figure S4). Comparing to male, female exhibited significantly higher incidence of having HSV infection for any type $(P<0.01)$ (Additional file 5: Figure S5), which might be partially attributed to more healthcare-seeking behaviour among females. As expected, the prevalence of HSV types increased with age ( $P_{\text {trend }}<0.01$ for both types): $66.08 \pm 1.24$ for HSV1 and $31.90 \pm 1.09$ for HSV2 among those aged 40-49 years compared to $51.36 \pm 1.31$ for HSV1 and $14.15 \pm 0.88$ for HSV2 among those aged 20-29 years (Fig. 1A). Elevated incidence of HSV2 infection was observed among nonHispanic black compared to non-Hispanic white and other race/ethnicity $(P<0.01): 57.83 \pm 1.27$ vs $20.01 \pm 0.74$ and $22.35 \pm 1.06$, respectively (Fig. 1B).

The weighted seroprevalences of both HSV1 and HSV2 were generally higher among sample persons with positive answer for any or specific type of cancer (Table 2), except a slightly lower prevalence of HSV2 among those participants with breast cancer $(23.64 \%$ vs $25.02 \%, P=0.88$ ). Crude logistic regression indicated HSV1 seropositivity was associated with cancer occurrence (any cancer) $(P=0.04)$ and uterine cancer $(P<0.01)$. HSV2 seropositivity was associated with cancer occurrence, cervical cancer and uterine cancer, but not breast cancer or ovarian cancer. In confounderadjusted logistic regression analysis, association between HSV1 seropositivity and uterine cancer was identified $\left(\mathrm{OR}_{\text {adjusted }}=6.03 ; 95 \% \mathrm{CI}: 1.52,23.87\right)$ while cancer occurrence was no longer associated with HSV1 seropositivity $(P=0.07)$. HSV2 seropositivity was associated with cancer occurrence $\left(\mathrm{OR}_{\text {adjusted }}=1.47 ; 95 \% \mathrm{CI}: 1.01,2.14\right)$, cervical cancer $\left(\mathrm{OR}_{\text {adjusted }}=1.72 ; 95 \% \mathrm{CI}: 1.06,2.79\right)$ 
Table 1 Weighted characteristics of the study populationNHANES 1999-2014

\begin{tabular}{|c|c|c|c|c|}
\hline Variable & Status & Number & $\begin{array}{l}\text { Weighted } \\
\text { percent }\end{array}$ & s.e. \\
\hline \multirow[t]{3}{*}{$\overline{\text { Age }}$} & $20-29$ years & 2676 & 28.74 & 0.71 \\
\hline & $30-39$ years & 2751 & 33.46 & 0.71 \\
\hline & $40-49$ years & 2757 & 37.80 & 0.73 \\
\hline \multirow[t]{3}{*}{ Race } & White & 3686 & 66.73 & 1.28 \\
\hline & Black & 1597 & 11.91 & 0.74 \\
\hline & Others & 2901 & 21.36 & 1.08 \\
\hline \multirow[t]{3}{*}{ Education } & $<$ high school & 1765 & 14.47 & 0.57 \\
\hline & $=$ high school & 1698 & 20.81 & 0.67 \\
\hline & >high school & 4721 & 64.71 & 0.94 \\
\hline \multirow[t]{3}{*}{ Poverty income ratio } & $<1$ & 1944 & 17.19 & 0.68 \\
\hline & $1 \leq \mathrm{PIR} \leq$ median & 2789 & 29.81 & 0.73 \\
\hline & >median & 3451 & 53.00 & 1.07 \\
\hline Body mass index & $\geq 25$ & 5362 & 60.39 & 0.84 \\
\hline \multirow[t]{3}{*}{ Smoking } & Current & 1821 & 24.10 & 0.70 \\
\hline & Former & 1172 & 16.02 & 0.64 \\
\hline & Non- & 5191 & 59.88 & 0.85 \\
\hline \multirow[t]{3}{*}{ Alcohol use } & Current & 4812 & 65.56 & 1.01 \\
\hline & Former & 518 & 5.94 & 0.33 \\
\hline & Non- & 2854 & 28.49 & 0.97 \\
\hline HIV & Yes & 20 & 0.16 & 0.04 \\
\hline Any cancer & Yes & 322 & 4.90 & 0.32 \\
\hline Breast cancer & Yes & 32 & 0.48 & 0.10 \\
\hline Cervical cancer & Yes & 128 & 1.79 & 0.19 \\
\hline Ovarian cancer & Yes & 24 & 0.30 & 0.08 \\
\hline Uterine cancer & Yes & 34 & 0.38 & 0.09 \\
\hline
\end{tabular}

Abbreviations: s.e., standard error; HIV, human immunodeficiency virus; NHANES, National Health and Nutrition Examination Survey and uterine cancer $\left(\mathrm{OR}_{\text {adjusted }}=3.49 ; 95 \% \mathrm{CI}: 1.03\right.$, 11.85) (Table 3). Adjusting BMI as continuous variable did not alter the results (Additional file 6: Table S1).

In the following analysis, the interaction between high-risk HPV (types 16 and 18) and HSV types was examined by using data from NHANES 2003-2010 $(n=4298)$ (Table 4). Rao-Scott chi-square test and adjusted logistic models indicated the association between HPV and HSV2 $\left(\mathrm{OR}_{\text {adjusted }}=2.49 ; 95 \% \mathrm{CI}\right.$ : $1.96,3.16)$, but not HSV1. In this subpopulation consisting of four survey cycles, HSV2 was still associated with cervical cancer $\left(\mathrm{OR}_{\text {adjusted }}=2.17 ; 95 \% \mathrm{CI}: 1.28\right.$, 3.66) after further adjusting HPV as confounder $\left(\mathrm{OR}_{\text {adjusted }}=1.90 ; 95 \% \mathrm{CI}: 1.09,3.34\right)$. Thus, serostatus of HSV2 could serve as an independent predictor for cervical cancer. In addition, a multiplicative interaction term between high-risk HPV and HSV2 was added to the main model, which indicated no significant result $\left(P_{\text {interaction }}=0.14\right)$. Relative risk $(\mathrm{RR})$-based analysis indicated significantly higher RR for cervical cancer in participants with seropositivity for only $\mathrm{HPV}\left(\mathrm{RR}_{\text {adjusted }}=2.98 ; 95 \% \mathrm{CI}: 1.23,7.20 ; P=0.02\right)$, only HSV2 $\left(\mathrm{RR}_{\text {adjusted }}=2.79 ; 95 \% \mathrm{CI}: 1.31,5.96\right.$; $P=0.01)$ or both viruses $\left(\mathrm{RR}_{\text {adjusted }}=3.44 ; 95 \% \mathrm{CI}\right.$ : $1.50,7.86 ; P<0.01$ ) when setting participants with seronegativity for both HPV and HSV2 as reference. However, the further increased RR of seropositivity for both HPV and HSV2 was not statistically significant comparing to those of only $\operatorname{HPV}(P=0.73)$ and only HSV2 $(P=0.65)$. In consistent with this analysis, females infected with only high-risk HPV, only HSV2, or both viruses showed significantly higher incidences of cervical cancer $(3.45 \pm 1.00,3.32 \pm 0.98$ and $4.14 \pm 1.25$, respectively) (Fig. 2 ).
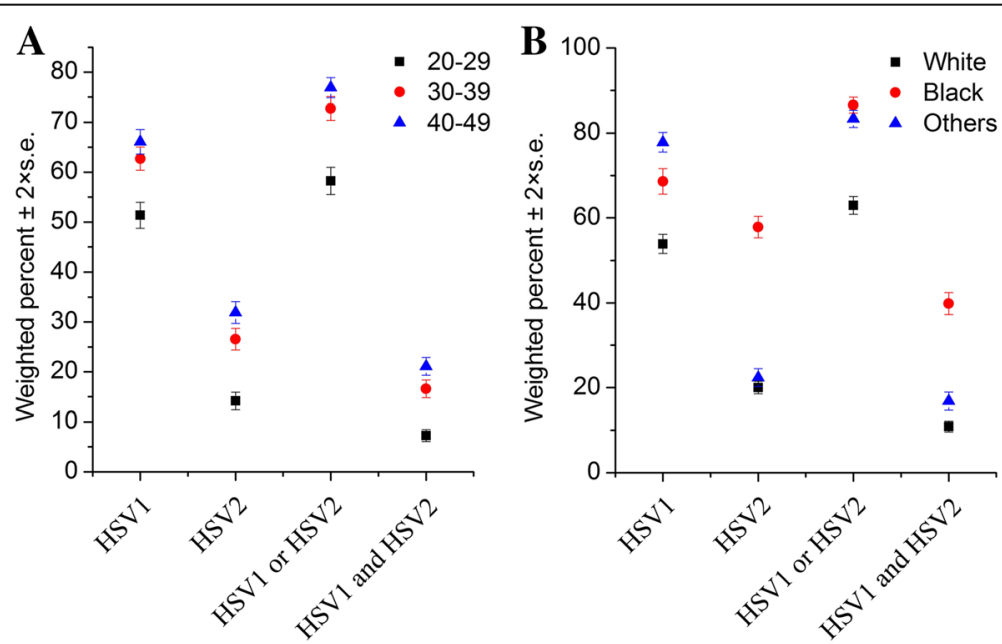

Fig. 1 Weighted sero-prevalences of human herpes simplex virus (HSV) type 1 and 2 according to age (a) and race (b) in study population-NHANES 1999-2014 
Table 2 Sero-prevalences of HSV type 1 and 2 according to cancer history-NHANES 1999-2014

\begin{tabular}{|c|c|c|c|c|c|c|}
\hline Variable & Status & HSV1+ number & HSV1- number & HSV1+ weighted percent & s.e. & $P$ value \\
\hline \multirow[t]{2}{*}{ Any cancer } & Yes & 229 & 93 & 67.17 & 3.12 & 0.04 \\
\hline & No & 5231 & 2631 & 60.39 & 0.91 & \\
\hline \multirow[t]{2}{*}{ Breast cancer } & Yes & 24 & 8 & 76.16 & 8.44 & 0.11 \\
\hline & No & 5436 & 2716 & 60.65 & 0.90 & \\
\hline \multirow[t]{2}{*}{ Cervical cancer } & Yes & 88 & 40 & 65.23 & 5.75 & 0.44 \\
\hline & No & 5372 & 2684 & 60.64 & 0.90 & \\
\hline \multirow[t]{2}{*}{ Ovarian cancer } & Yes & 21 & 3 & 77.82 & 11.77 & 0.22 \\
\hline & No & 5439 & 2721 & 60.68 & 0.90 & \\
\hline \multirow[t]{2}{*}{ Uterine cancer } & Yes & 30 & 4 & 92.24 & 4.51 & $<0.01$ \\
\hline & No & 5430 & 2720 & 60.61 & 0.90 & \\
\hline Variable & Status & HSV2+ number & HSV2- number & HSV2+ weighted percent & s.e. & $P$ value \\
\hline \multirow[t]{2}{*}{ Any cancer } & Yes & 119 & 203 & 34.26 & 3.51 & $<0.01$ \\
\hline & No & 2144 & 5718 & 24.54 & 0.66 & \\
\hline \multirow[t]{2}{*}{ Breast cancer } & Yes & 8 & 24 & 23.64 & 9.23 & 0.88 \\
\hline & No & 2255 & 5897 & 25.02 & 0.64 & \\
\hline \multirow[t]{2}{*}{ Cervical cancer } & Yes & 56 & 72 & 40.05 & 5.41 & $<0.01$ \\
\hline & No & 2207 & 5849 & 24.74 & 0.65 & \\
\hline \multirow[t]{2}{*}{ Ovarian cancer } & Yes & 11 & 13 & 44.41 & 12.95 & 0.09 \\
\hline & No & 2252 & 5908 & 24.96 & 0.65 & \\
\hline \multirow[t]{2}{*}{ Uterine cancer } & Yes & 15 & 19 & 57.99 & 11.61 & $<0.01$ \\
\hline & No & 2248 & 5902 & 24.89 & 0.65 & \\
\hline
\end{tabular}

Abbreviations: HSV1, herpes simplex virus type 1; HSV2, herpes simplex virus type 2; +, positive; -, negative; s.e., standard error; NHANES, National Health and Nutrition Examination Survey

Table 3 Associations between HSV types 1 or 2 and cancer status-NHANES 1999-2014

\begin{tabular}{llll}
\hline HSV1 & aOR & $(95 \% \mathrm{Cl})$ & $P$ value \\
\hline Any cancer & 1.32 & $(0.97-1.79)$ & 0.07 \\
Breast cancer & 2.04 & $(0.78-5.37)$ & 0.14 \\
Cervical cancer & 1.04 & $(0.60-1.80)$ & 0.89 \\
Ovarian cancer & 1.57 & $(0.37-6.64)$ & 0.54 \\
Uterine cancer & 6.03 & $(1.52-23.87)$ & 0.01 \\
HSV2 & $\mathrm{aOR}$ & $(95 \% \mathrm{Cl})$ & $P$ value \\
Any cancer & 1.47 & $(1.01-2.14)$ & 0.04 \\
Breast cancer & 0.69 & $(0.20-2.40)$ & 0.56 \\
Cervical cancer & 1.72 & $(1.06-2.79)$ & 0.03 \\
Ovarian cancer & 1.56 & $(0.50-4.94)$ & 0.44 \\
Uterine cancer & 3.49 & $(1.03-11.85)$ & 0.04 \\
\hline
\end{tabular}

Abbreviations: HSV1, herpes simplex virus type 1; HSV2, herpes simplex virus type 2; aOR, Adjusted odds ratio; $\mathrm{Cl}$, confidence interval; NHANES, National Health and Nutrition Examination Survey

Model was adjusted for age, education, race, poverty income ratio, body mass index, smoking status, alcohol-use status and HIV status

\section{Discussion}

The association of cervical cancer with sexual behavior has been illustrated by many investigations since 1842 . These studies led to the discovery of cervical cancerinducing sexually-transmitted agents such as HPV [4]. However, whether HSV is involved in carcinogenesis is still controversial [18]. We examined this long-held idea using NHANES data which represents non-institutional civilian U.S. population (Table 1), and found that prevalence of HSV were usually higher among those female

Table 4 Associations between HSV and HPV, and their associations with cervical cancer-NHANES 2003-2010

\begin{tabular}{lllll}
\hline Dependent variable & Independent variable & aOR & $(95 \% \mathrm{Cl})$ & $P$ value \\
\hline HPV16or18 $^{\mathrm{a}}$ & $\mathrm{HSV} 1$ & 1.03 & $(0.84-1.27)$ & 0.75 \\
HPV16or18 $^{\mathrm{a}}$ & $\mathrm{HSV} 2$ & 2.49 & $(1.96-3.16)$ & $<0.01$ \\
Cervical cancer $^{\mathrm{a}}$ & HPV16or18 & 2.26 & $(1.14-4.45)$ & 0.02 \\
Cervical cancer $^{\mathrm{a}}$ & $\mathrm{HSV} 2$ & 2.17 & $(1.28-3.66)$ & 0.00 \\
Cervical cancer $^{\mathrm{b}}$ & HSV2 & 1.90 & $(1.09-3.34)$ & 0.02
\end{tabular}

Abbreviations: HSV1, herpes simplex virus type 1; HSV2, herpes simplex virus type 2; HPV16or18, human papillomavirus type 16 or 18; aOR, Adjusted odds ratio; $\mathrm{Cl}$, confidence interval; NHANES, National Health and Nutrition Examination Survey ${ }^{a}$ Model was adjusted for age, education, race, poverty income ratio, body mass index, smoking status, alcohol-use status and HIV status

${ }^{\mathrm{b}}$ Model was further adjusted for HPV status 


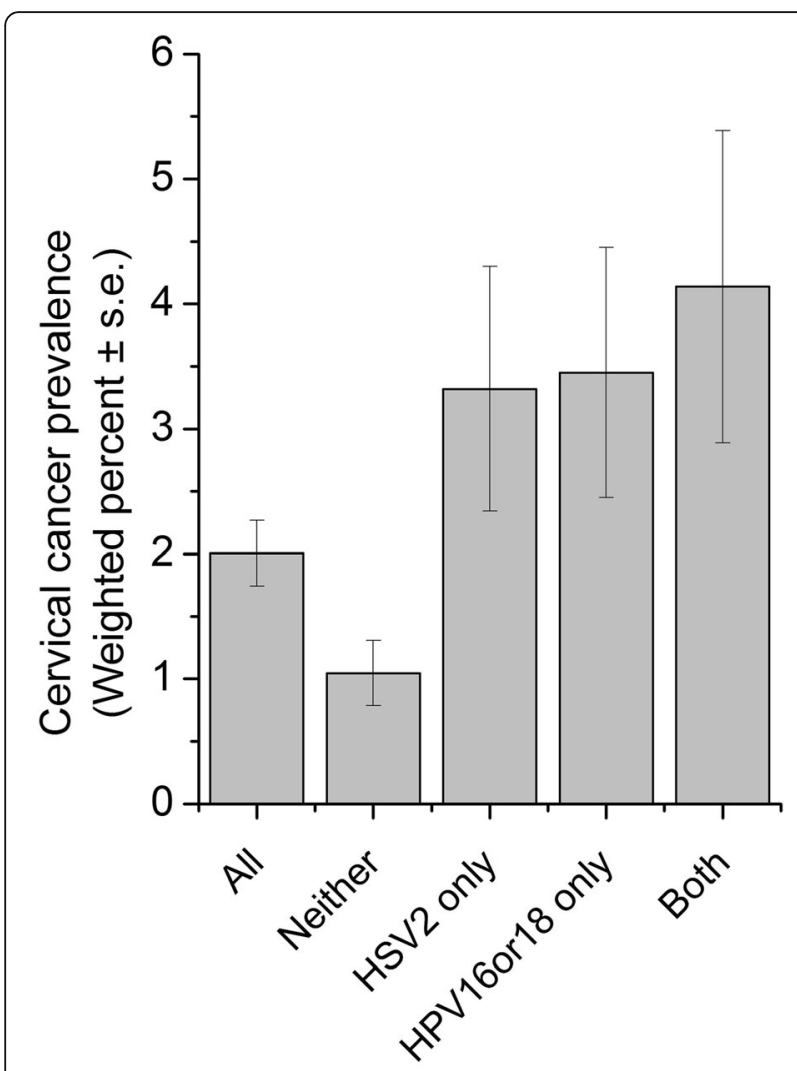

Fig. 2 Weighted prevalence of cervical cancers according to HSV2 and high risk-HPV infection status-NHANES 2003-2010

with any or specific type of cancer (Table 2). This is consistent with several clinical findings: higher frequency of occurrence of HSV2 has been observed in invasive cervical cancer cases comparing to cases without neoplastic lesions [19]. Similarly, a significantly higher positivity of HSV2 has been found in women with cervical dysplasia and carcinoma-in-situ [20]. Moreover, compared to HPV DNA-positive normal controls, seropositivity of HSV2 is significantly greater in cases with cervical cancer [21]. As reported by an epidemiological study, higher levels of HSV2 antibodies have been found more common in cervical cancer patients [22]. Our subsequent multivariate logistic regression analysis indicated that 1) HSV1 seropositivity was associated with uterine cancer, and 2) HSV2 seropositivity was associated with cancer occurrence, cervical cancer and uterine cancer (Table 3). Indeed, high HSV2 prevalence has been related to highrisk area of cervical cancer [23]. For instance, The highest incidence of cervical cancer was in Africa as reported by GLOBOCAN project which provides contemporary estimates of the incidence of major types of cancer [24]. Such high incidence of cervical cancer may be partially attributed to high prevalence of HSV2 (around 70\%) among women in Africa [25]. Moreover, an increased risk of cervical cancer in women with antibodies against
HSV2 has been suggested by several studies [26-28]. One study showed that those female with positive HSV2 testing results have a $60 \%$ increased risk of cervical cancer in contrast to HSV2 seronegative women [27], while another study indicated this risk can be two- to three-fold higher [29]. In a prospective study, incidences of cancer are directly related to the prevalence of genital herpes symptoms [30]. Furthermore, immuno-cytochemistry suggested HSV2 is probably associated with squamous cell carcinoma cervix and carcinoma in situ [31], indicating that HSV2 may play separate etiologic roles in cervical malignant transformation [32]. Globally, the possible association between HSV2 seroprevalence and cervical cancer has been known to differ markedly across various countries [21]. A study in Nepal indicates that HSV2 is detected in $11 \%$ cases of cervical intraepithelial neoplasia (CIN) I, 33\% cases of CIN III and 40\% cases of carcinoma cervix with a gradual increasing antibody titre [33]. In India, HSV, diagnosed in cytology smears, is largely associated with squamous intraepithelial lesion and carcinoma cervix even with higher affinity compared to HPV [34]. The independent effect of HSV2 seropositivity in cervical malignant transformation is also found in Latin American [27]. In contrast, such association is not identified in the south of Brazil [35], China [36], Jamaica [37] and Nordic countries [38]. These inconsistencies may also derive from differences in detection methods and severity of cervical lesions [35]. It is of note that HSV genes may be necessary for the initiation, but not progression in cervical malignant transformation as proposed by "hit and run" mechanism [39].

The role of HSV2 in in vivo carcinogenesis has been confirmed in animal models. Prolonged exposure of formalin or ultraviolet inactivated HSV1 or 2 leads to premalignant or malignant lesions in mouse cervix [40]. HSV2 DNA transfection also induces cervical neoplasia reflected by premalignant or malignant lesions on vaginal smears with similar cytologic and histologic characteristics of that occurred in women [41]. At cellular and molecular level, transfection with HSV2 morphological transforming region III (MTR III) leads to morphological transformation in HPV-immortalized keratinocytes, and lesions can be developed when injecting these cells to nude mice [42]. Moreover, HSV2-infection in cervical cancer cell line rapidly increases the proportions of DNA-synthesizing G1- and S-phase cells, resulting in unscheduled DNA synthesis [43]. Accumulative evidences from biological experiments suggest that HSV gene products interfere with cell cycle control, induce accumulation of genetic abnormalities and destabilize host genome, indicating a role of HSV in cellular malignant transformation.

On the other hand, the causative role of HPV in cervical carcinogenesis appears to be incontrovertible [44, 45]. 40 
of 120 types of HPVs discovered to date are involved in anogenital infections [46], in which HPV types 16 and 18 are the major etiological factors of cervical cancer causing $70 \%$ of all cases [47]. The mechanism of HPV-mediated carcinogenesis is relatively clear. HPV integration into the host DNA disrupts E2 gene and results in the removal of its transcriptional repression on E6/E7, which is known to immortalize primary cervical cells and human foreskin keratinocytes in culture [48, 49]. More specifically, the E6 oncoprotein of high-risk HPVs effectively binds to p53 and leads to its degradation via ubiquitin mediated pathway. This disabled chromosomal repair in damaged cells. Continuous division of damaged cells increases chromosomal mutations, and hence the development of carcinoma [18]. However, HPV infection alone is neither sufficient nor necessary for malignant transformation [50]. In females with high-risk HPV infection, only a small proportion will develop invasive cervical cancer over years [35]. It is consistent with evidence from cell experiments that HPV genes can immortalize normal cells, but are incapable of their transformation [50]. Numerous evidences of cervical cancer occurrences in HPV-negative population also deny the postulate that about $90 \%$ of cervical cancer is caused by HPV $[4,51]$. Thus, additional factors besides HPV may be necessary to convert dysplastic lesions to carcinomas, reflecting the multifactorial etiology of cervical carcinogenesis [52].

Next, we want to investigate whether both HSV2 and HPV infection have synergistic functions in cancer development. STDs normally occur with high level of concordance, which is supported by our result showing that HPV was associated with HSV2, but not HSV1 (Table 4). Furthermore, relative risk-based interaction measurement between HSV and HPV on the additive scale suggests that participants with seropositivity for both HPV and HSV2 showed a relatively higher risk for cervical cancer (Table 4). Indeed, synergistic interactions between HPV and HSV have been reported in case-control study [27]. HSV may interact directly with HPV to facilitate its integration and amplification in host cells, thereby elevating the risk of cervical cancer [53-55]. Mechanistically, co-infection HSV2 with HPV interfere local immune responses, which increases the likelihood of HPV-associated lesions progression [37]. More importantly, tumorigenic growth can be induced by HSV in cells immortalized by HPV16 [42, 52], and HSV2 transfection is also required for tumours induction in mice by HPV16/18 transformed cells [56]. Thus, HSV2 play roles in immortalisation and cooperates in the process of malignant transformation.

In order to exclude the possibility that infection with HSV2 serves as surrogate marker of HPV exposure, and is of no separate aetiological significance $[26,57]$, we further adjusted HPV as confounder. The results consistently indicated that HSV2 seropositivity was associated with cervical cancer (Table 4). The role of HSV2 as independent predictor for cervical cancer is supported by several studies. Zhao et al. reveals that HSV2, but not HSV1, infection or co-infection with HPV is involved in cervical malignant transformation [58]. The association between HSV seropositivity and CIN grade II-III exists, and cannot be explained by HPV [59]. Moreover, HSV2 antibodies were associated with cervical cancer in HPVnegative cases, revealing HSV2 as primary viral agent [60].

\section{Conclusions}

The observed associations between HSV seropositivity and cancer occurrence in this study merits further investigation. Unlike HPV, there is currently no effective vaccine against herpes virus, which makes current study particularly important. More fundamental research on cervical carcinogenesis is needed to elucidate the etiology of such multifactorial disease and better prevent, treat and cure cervical cancer that causes high morbidity and mortality among females globally.

\section{Additional files} Additional file 1: Figure S1. NHANES participant enrollment flowchart
including exclusion criteria. (JPEG $814 \mathrm{~kb}$ )

Additional file 2: Figure S2. Weighted percent of human papillomavirus (HPV) vaccination according to NHANES survey cycles (A) and age (B) in female population-NHANES 2007-2014 ( $n=4375)$. (JPEG $203 \mathrm{~kb}$ )

Additional file 3: Figure S3. Weighted prevalences of occurrence of any type of cancer (A) and cervical cancer (B) according to age in study population-NHANES 1999-2014. (JPEG 250 kb)

Additional file 4: Figure S4. Weighted sero-prevalences of human herpes simplex virus (HSV) type 1 and 2 according to NHANES survey cycles. (JPEG $286 \mathrm{~kb}$ )

Additional file 5: Figure S5. Weighted sero-prevalences of human herpes simplex virus (HSV) type 1 and 2 according to gender in population consisting of both genders ( $n=16,734)-N H A N E S$ 1999-2014. (JPEG 211 kb)

Additional file 6: Table S1. Associations between HSV types 1 or 2 and cancer status-NHANES 1999-2014. (DOCX 14 kb)

\section{Abbreviations}

BMI: body mass index; CDC: Centers for Disease Control and Prevention; $\mathrm{Cl}$ : confidence interval; CIN: Cervical intraepithelial neoplasia; Cls: confidence intervals; HIV: human immunodeficiency virus; HPV: human papillomavirus; HPV16or18: human papillomavirus type 16 or 18; HSV: herpes simplex virus; MTR III: morphological transforming region III; NCHS: National Centers for Health Statistics; NHANES: National Health and Nutrition Examination Survey;

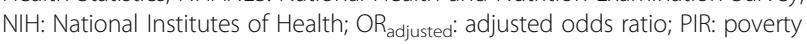
income ratio; RR: Relative risk; s.e.: standard error; STDs: sexually transmitted diseases

\section{Acknowledgments}

We thank Dr. Biao Zhang from Peking Union Medical College for his valuable suggestions during manuscript preparation and revision.

\section{Funding}

This study is supported by grants from BUCM research program (to SL) and $\mathrm{NIH}$ intramural research program (to XW). The funding bodies of present study had no role in study design, data collection, data analysis, data interpretation, or manuscript writing. 


\section{Availability of data and materials}

The data used in this study is from NHANES 1999-2014. Data are publicly available, and can be downloaded from NHANES website: http://www.cdc.gov/nchs/nhanes.htm.

\section{Authors' contributions}

$\mathrm{SL}$ designed the study, carried out the statistical analysis and drafted the manuscript. XW contributed to the discussion and critically reviewed the manuscript. Both authors read and approved the final manuscript.

\section{Ethics approval and consent to participate}

Data analyzed in this study were obtained from NHANES. Protocols involved were approved by the National Center for Health Statistics (NCHS) Research Ethics Review Board (ERB), and consent from all participants was documented. This study is a secondary data analysis using existing, de-identified, publicly available NHANES data, and no further ethical approval is required according to US Health \& Human Services (HHS)' regulations (available from http:// www.hhs.gov/ohrp/policy/cdebiol.html, accessed October 2017) [61].

\section{Consent for publication}

Not applicable.

\section{Competing interests}

The authors declare that they have no competing interests.

\section{Publisher's Note}

Springer Nature remains neutral with regard to jurisdictional claims in published maps and institutional affiliations.

\section{Author details}

'School of Life Sciences, Beijing University of Chinese Medicine, Beijing, China. ${ }^{2}$ Department of Physiology, LKS Faculty of Medicine, University of Hong Kong, Hong Kong, China. ${ }^{3}$ Laboratory of immunogenetics, National Institute of Allergy and Infectious Diseases, National Institutes of Health, Bethesda, MD, USA.

\section{Received: 19 December 2016 Accepted: 30 October 2017}

\section{Published online: 07 November 2017}

\section{References}

1. World Cancer Report 2014. World Health Organization 2014, pp. Chapter 5.12

2. World Cancer Report 2014. World Health Organization 2014, pp. Chapter 1.1.

3. National Institutes of Health, National Cancer Institute: PDQ ${ }^{\oplus}$ Cervical Cancer Treatment. Date last modified 2/4/2016.

4. Haverkos H, Rohrer M, Pickworth W. The cause of invasive cervical cancer could be multifactorial. Biomedicine \& pharmacotherapy = Biomedecine \& pharmacotherapie. 2000;54(1):54-9.

5. Macnab JC, Kitchener HC. Sexually transmitted cancers and viruses. Biomedicine \& pharmacotherapy = Biomedecine \& pharmacotherapie. 1989; 43(3):167-72.

6. Bradley H, Markowitz LE, Gibson T, McQuillan GM. Seroprevalence of herpes simplex virus types 1 and 2-United States, 1999-2010. J Infect Dis. 2014; 209(3):325-33.

7. Wald A. Genital HSV-1 infections. Sex Transm Infect. 2006;82(3):189-90.

8. Menczer J, Leventon-Kriss S, Modan M, Oelsner G, Gerichter CB. Antibodies to herpes simplex virus in Jewish women with cervical cancer and in healthy Jewish women of Israel. J Natl Cancer Inst. 1975;55(1):3-6.

9. Mendis LN, Best JM, Banatvala JE. Class-specific antibodies (IgG and IgA) to membrane antigens of herpes simplex type 2 -infected cells in patients with cervical dysplasia and neoplasia. Int J Cancer. 1981;27(5):669-77.

10. Frenkel N, Roizman B, Cassai E, Nahmias A. A DNA fragment of herpes simplex 2 and its transcription in human cervical cancer tissue. Proc Nat Acad Sci U S A. 1972;69(12):3784-9.

11. Vonka V, Kanka J, Hirsch I, Zavadova H, Krcmar M, Suchankova A, Rezacova D, Broucek J, Press M, Domorazkova E, et al. Prospective study on the relationship between cervical neoplasia and herpes simplex type-2 virus. II. Herpes simplex type-2 antibody presence in sera taken at enrollment. Int J Cancer. 1984:33(1):61-6.

12. Maitland NJ. The aetiological relationship between herpes simplex virus type 2 and carcinoma of the cervix: an unanswered or unanswerable question? Cancer Surv. 1988;7(3):457-67.
13. Wilkinson DE, Weller SK. Herpes simplex virus type I disrupts the ATRdependent DNA-damage response during lytic infection. J Cell Sci. 2006; 119(Pt 13):2695-703.

14. Jensen K, Patel A, Larin A, Hoperia V, Saji M, Bauer A, Yim K, Hemming V, Vasko V. Human herpes simplex viruses in benign and malignant thyroid tumours. J Pathol. 2010:221(2):193-200.

15. Centers for Disease Control and Prevention (CDC). National Center for Health Statistics (NCHS). National Health and nutrition examination survey data. Hyattsville, MD: U.S. Department of Health and Human Services, centers for disease control and Prevention, 2016, http://www.cdc.gov/nchs/ nhanes/nhanes questionnaires.htm.

16. Opalka D, Lachman CE, MacMullen SA, Jansen KU, Smith JF, Chirmule N, Esser MT. Simultaneous quantitation of antibodies to neutralizing epitopes on virus-like particles for human papillomavirus types $6,11,16$, and 18 by a multiplexed luminex assay. Clin Diagn Lab Immunol. 2003;10(1):108-15.

17. Centers for Disease Control and Prevention (CDC). National Center for Health Statistics (NCHS). National Health and nutrition examination survey laboratory protocol. Hyattsville, MD: U.S. Department of Health and Human Services, centers for disease control and Prevention, 2016, http://www.cdc. gov/NCHS/data/nhanes/nhanes_09_10/hsv_f_met_herpes_1_2.pdf.

18. Boyle DC, Smith JR. Infection and cervical intraepithelial neoplasia. International journal of gynecological cancer: official journal of the International Gynecological Cancer. Society. 1999;9(3):177-86.

19. Kwasniewska A, Korobowicz E, Zdunek M, Skoczynski M, Kwasniewski W, Danilos J, Gozdzicka-Jozefiak A. Prevalence of chlamydia trachomatis and herpes simplex virus 2 in cervical carcinoma associated with human papillomavirus detected in paraffin-sectioned samples. Eur J Gynaecol Oncol. 2009;30(1):65-70.

20. Gupta MM, Sharma BK, Singh V, Luthra UK. Immunocytological demonstration of HSV-II antigen on exfoliated cells from precancerous and cancerous lesions of the uterine cervix. Diagn Cytopathol. 1988;4(1):48-9.

21. Smith JS, Herrero R, Bosetti C, Munoz N, Bosch FX, Eluf-Neto J, Castellsague X, Meijer CJ, Van den Brule AJ, Franceschi S et al: Herpes simplex virus-2 as a human papillomavirus cofactor in the etiology of invasive cervical cancer. J Natl Cancer Inst 2002, 94(21):1604-1613.

22. Franceschi S, Doll R, Gallwey J, La Vecchia C, Peto R, Spriggs Al. Genital warts and cervical neoplasia: an epidemiological study. Br J Cancer. 1983; 48(5):621-8.

23. Kjaer SK, de Villiers EM, Caglayan H, Svare E, Haugaard BJ, Engholm G, Christensen RB, Moller KA, Poll P, Jensen $H$, et al. Human papillomavirus, herpes simplex virus and other potential risk factors for cervical cancer in a high-risk area (Greenland) and a low-risk area (Denmark)-a second look. Br J Cancer. 1993;67(4):830-7.

24. Ferlay J SI, Ervik M, Dikshit R, Eser S, Mathers C, Rebelo M, Parkin DM, Forman D, Bray, F: GLOBOCAN, cancer incidence and mortality worldwide. 2012.

25. Looker KJ, Garnett GP, Schmid GP: An estimate of the global prevalence and incidence of herpes simplex virus type 2 infection. Bulletin of the World Health Organization 2008, 86(10):805-812, a.

26. de Sanjose S, Munoz N, Bosch FX, Reimann K, Pedersen NS, Orfila J, Ascunce N, Gonzalez LC, Tafur L, Gili M, et al. Sexually transmitted agents and cervical neoplasia in Colombia and Spain. Int J Cancer. 1994;56(3):358-63.

27. Hildesheim A, Mann V, Brinton LA, Szklo M, Reeves WC, Rawls WE. Herpes simplex virus type 2: a possible interaction with human papillomavirus types 16/18 in the development of invasive cervical cancer. Int J Cancer. 1991;49(3):335-40.

28. Becker TM, Wheeler CM, McGough NS, Parmenter CA, Jordan SW, Stidley CA, McPherson RS, Dorin MH. Sexually transmitted diseases and other risk factors for cervical dysplasia among southwestern Hispanic and nonHispanic white women. JAMA. 1994;271(15):1181-8.

29. Rawls WE, Tompkins WA, Figueroa ME, Melnick JL. Herpesvirus type 2: association with carcinoma of the cervix. Science (New York, NY). 1968; 161(3847):1255-6.

30. Grossarth-Maticek R, Frentzel-Beyme R, Kanazir D, Jankovic M, Vetter H. Reported herpes-virus-infection, fever and cancer incidence in a prospective study. J Chronic Dis. 1987:40(10):967-76.

31. Pandit AA, Khilnani PH, Powar H, Bhave GG, Chadda NO. Detection of HSV-2 antigen in carcinoma cervix and premalignant conditions by immunocytochemistry. J Postgrad Med. 1990;36(4):185-90.

32. Koffa M, Koumantakis E, Ergazaki M, Tsatsanis C, Spandidos DA. Association of herpesvirus infection with the development of genital cancer. Int J Cancer. 1995;63(1):58-62. 
33. Bashyal R, Dali S. Study on koilocytosis, X-chromatin and HSV-2 in cervical smears in Nepal. Nepal Medical College journal : NMCJ. 2004;6(1):45-8.

34. Misra JS, Srivastava S, Singh U, Srivastava AN. Risk-factors and strategies for control of carcinoma cervix in India: hospital based cytological screening experience of 35 years. Indian J Cancer. 2009;46(2):155-9.

35. Zereu M, Zettler CG, Cambruzzi E, Zelmanowicz A. Herpes simplex virus type 2 and chlamydia trachomatis in adenocarcinoma of the uterine cervix. Gynecol Oncol. 2007;105(1):172-5.

36. Peng HQ, Liu SL, Mann V, Rohan T, Rawls W. Human papillomavirus types 16 and 33, herpes simplex virus type 2 and other risk factors for cervical cancer in Sichuan Province, China. Int J Cancer. 1991;47(5):711-6.

37. Castle PE, Escoffery C, Schachter J, Rattray C, Schiffman M, Moncada J, Sugai K, Brown C, Cranston B, Hanchard B, et al. Chlamydia trachomatis, herpes simplex virus 2, and human T-cell lymphotrophic virus type 1 are not associated with grade of cervical neoplasia in Jamaican colposcopy patients. Sex Transm Dis. 2003;30(7):575-80.

38. Lehtinen M, Koskela P, Jellum E, Bloigu A, Anttila T, Hallmans G, Luukkaala T, Thoresen S, Youngman L, Dillner J, et al. Herpes simplex virus and risk of cervical cancer: a longitudinal, nested case-control study in the nordic countries. Am J Epidemiol. 2002;156(8):687-92.

39. Galloway DA, McDougall JK. The oncogenic potential of herpes simplex viruses: evidence for a 'hit-and-run' mechanism. Nature. 1983;302(5903):21-4

40. Wentz WB, Reagan JW, Heggie AD, YS F, Anthony DD. Induction of uterine cancer with inactivated herpes simplex virus, types 1 and 2. Cancer. 1981; 48(8):1783-90.

41. Anthony DD, Wentz WB, Reagan JW, Heggie AD. Induction of cervical neoplasia in the mouse by herpes simplex virus type 2 DNA. Proc Natl Acad Sci U S A. 1989;86(12):4520-4.

42. Dhanwada KR, Garrett L, Smith P, Thompson KD, Doster A, Jones C. Characterization of human keratinocytes transformed by high risk human papillomavirus types 16 or 18 and herpes simplex virus type 2 . The Journal of general virology. 1993;74(Pt 6):955-63.

43. Kulomaa P, Paavonen J, Lehtinen M. Herpes simplex virus induces unscheduled DNA synthesis in virus-infected cervical cancer cell lines. Res Virol. 1992;143(5):351-9.

44. Koutsky LA, Holmes KK, Critchlow CW, Stevens CE, Paavonen J, Beckmann AM, DeRouen TA, Galloway DA, Vernon D, Kiviat NB. A cohort study of the risk of cervical intraepithelial neoplasia grade 2 or 3 in relation to papillomavirus infection. N Engl J Med. 1992;327(18):1272-8.

45. Ho GY, Burk RD, Klein S, Kadish AS, Chang CJ, Palan P, Basu J, Tachezy R, Lewis R, Romney S. Persistent genital human papillomavirus infection as a risk factor for persistent cervical dysplasia. J Natl Cancer Inst. 1995;87(18):1365-71.

46. Szostek S, Zawilinska B, Kopec J, Kosz-Vnenchak M. Herpesviruses as possible cofactors in HPV-16-related oncogenesis. Acta Biochim Pol. 2009;56(2):337-42.

47. Zhao Y, Cao X, Tang J, Zhou L, Gao Y, Wang J, Zheng Y, Yin S, Wang Y. A novel multiplex real-time PCR assay for the detection and quantification of HPV16/18 and HSV1/2 in cervical cancer screening. Mol Cell Probes. 2012; 26(2):66-72

48. Kaur P, McDougall JK, Cone R. Immortalization of primary human epithelial cells by cloned cervical carcinoma DNA containing human papillomavirus type 16 E6/E7 open reading frames. The Journal of general virology. 1989; 70(Pt 5):1261-6.

49. Hawley-Nelson P, Vousden KH, Hubbert NL, Lowy DR, Schiller JT. HPV16 E6 and E7 proteins cooperate to immortalize human foreskin keratinocytes. EMBO J. 1989;8(12):3905-10.

50. Southern SA, Herrington CS. Molecular events in uterine cervical cancer. Sex Transm Infect. 1998:74(2):101-9.

51. Blatt AJ, Kennedy R, Luff RD, Austin RM, Rabin DS. Comparison of cervical cancer screening results among 256,648 women in multiple clinical practices. Cancer cytopathology. 2015;123(5):282-8

52. DiPaolo JA, Woodworth CD, Popescu NC, Koval DL, Lopez JV, Doniger J. HSV-2-induced tumorigenicity in HPV16-immortalized human genital keratinocytes. Virology. 1990;177(2):777-9.

53. DiPaolo JA, Woodworth CD, Coutlee F, Zimonic DB, Bryant J, Kessous A. Relationship of stable integration of herpes simplex virus-2 Bg/ll N subfragment Xho2 to malignant transformation of human papillomavirusimmortalized cervical keratinocytes. Int J Cancer. 1998;76(6):865-71.

54. Galloway DA, McDougall JK. Alterations in the cellular phenotype induced by herpes simplex viruses. J Med Virol. 1990;31(1):36-42.

55. Hara $Y$, Kimoto T, Okuno Y, Minekawa Y. Effect of herpes simplex virus on the DNA of human papillomavirus 18. J Med Virol. 1997:53(1):4-12.
56. Iwasaka T, Yokoyama M, Hayashi Y, Sugimori H. Combined herpes simplex virus type 2 and human papillomavirus type 16 or 18 deoxyribonucleic acid leads to oncogenic transformation. Am J Obstet Gynecol. 1988;159(5):1251-5.

57. Jha PK, Beral V, Peto J, Hack S, Hermon C, Deacon J, Mant D, Chilvers C, Vessey MP, Pike MC, et al. Antibodies to human papillomavirus and to other genital infectious agents and invasive cervical cancer risk. Lancet (London, England). 1993;341(8853):1116-8.

58. Zhao Y, Cao X, Zheng Y, Tang J, Cai W, Wang H, Gao Y, Wang Y. Relationship between cervical disease and infection with human papillomavirus types 16 and 18, and herpes simplex virus 1 and 2. J Med Virol. 2012;84(12):1920-7.

59. Olsen AO, Orstavik I, Dillner J, Vestergaard BF, Magnus P. Herpes simplex virus and human papillomavirus in a population-based case-control study of cervical intraepithelial neoplasia grade II-III. APMIS : acta pathologica, microbiologica, et immunologica Scandinavica. 1998;106(3):417-24.

60. Daling JR, Madeleine MM, McKnight B, Carter JJ, Wipf GC, Ashley R, Schwartz SM, Beckmann AM, Hagensee ME, Mandelson MT, et al. The relationship of human papillomavirus-related cervical tumors to cigarette smoking, oral contraceptive use, and prior herpes simplex virus type 2 infection. Cancer epidemiology, biomarkers \& prevention : a publication of the American Association for Cancer Research, cosponsored by the American Society of Preventive Oncology. 1996:5(7):541-8.

61. Wang Y, Lopez JM, Bolge SC, Zhu VJ, Stang PE. Depression among people with type 2 diabetes mellitus, US National Health and nutrition examination survey (NHANES), 2005-2012. BMC psychiatry. 2016;16:88.

\section{Submit your next manuscript to BioMed Central and we will help you at every step:}

- We accept pre-submission inquiries

- Our selector tool helps you to find the most relevant journal

- We provide round the clock customer support

- Convenient online submission

- Thorough peer review

- Inclusion in PubMed and all major indexing services

- Maximum visibility for your research

Submit your manuscript at www.biomedcentral.com/submit
) Biomed Central 